\title{
STUDENTS' INTERNET ACCESS, INTERNET SELF-EFFICACY, AND INTERNET FOR LEARNING PHYSICS: GENDER AND GRADE DIFFERENCES
}

\author{
Wayan Suana (iD \\ Faculty of Teacher Training and Education, University of Lampung (Indonesia) \\ wsuane@gmail.com
}

Received February 2018

Accepted March 2018

\section{Abstract}

This paper aims to analyze the differences between internet facilities, internet usage purposes, internet selfefficacy (ISE), and internet perceptions in learning physics, regarding students' gender and grade. A total of 798 senior high school students were surveyed randomly from 10 schools in the urban area of Lampung Province, Indonesia. The data were analyzed with Chi-square tests, t-test and ANOVA test for parametric, and Mann-Withney test and Kruskal-Wallis test for nonparametric. The results showed that by gender, female students were better at the ownership of computers and internet access via mobile phones. For the purpose of accessing internet, they were also identified more frequently in using internet for academic purposes, social media, and doing physics homework. Additionally, females were better at the perception about the benefit of the internet in learning physics. Besides, males were higher in using internet for entertainment and accessing physics' video and animation. For experience and frequency in accessing internet and ISE, there were no significant gender differences found. Meanwhile, the differences were found between grades in some general usage as well as in ISE. Overall, the higher the students' grade, the greater the percentage of students who use them, except in internet perception.

Keywords - Gender and grade differences, Internet for learning physics, Internet self-efficacy (ISE), Internet access, Students' perception.

\section{Introduction}

In the last two decades, technology has brought radical change in many areas including educational system, the way of teaching and learning, people's way of thinking and behaving, and the shift on the way we conceive gender differences (Goktas, Gedik \& Baydas, 2013; Thanuskodi, 2013; Vekiri \& Chronaki, 2008; Zhou \& Xu, 2007). Gender differences have become popular in educational research and practice since it attracted numerous debates. There are a large number of studies that were set up on gender disparity in computer usage in a different level and setting in the last two decades. During the $20^{\text {th }}$ century, a couple of units has revealed that an unequal representation of women and men in the technological field. Girls tend to have less favorable perceptions, less interest in computer, less frequent of accessing internet, lower self-efficacy about the internet, less computer experience, less skilled and less computer access than their males peers (Nelson \& Cooper, 1997; Schumacher \& Morahan-Martin, 2001; Weiser, 2000).

Some other works, on the other hand, reported inconsistent results regarding gender gap. The results of recent studies suggested that the gender gap has seemed to be narrowing or even reversed. An analysis of gender differences at the University of Frankfurt showed surprising information that there was no gender gap regarding computer self-belief, computer use, and frequency of computer use (Imhof, Vollmeyer \& Beierlein, 
2007). Another study revealed that there were no longer significant differences in males and females' attitudes toward computer, computer courses, and frequency of internet use (Popovic, Gullekson, Morris \& Morse, 2008). Tsai \& Tsai (2010) provided another interesting evidence that women had significantly higher communicative ISE than had the men. In other words, girls are more confident than boys in online communication. In their study, the gap in internet experience and computer ownership between males and females were no longer appears and become statistically insignificant excepted in their motives and internet usage intensity (Tsai \& Tsai, 2010). Moreover, Imhof et al. (2007) described a consistent situation where men tend to use internet as entertainment, personal or non-academic activities than their females' peers. The similar finding was also reported by Tsai (2006) where boys prefer to use internet primarily as entertainment tool while it becomes a communication tool for girls. Men became exploration-oriented users and women were more communicative oriented (Tsai \& Tsai, 2010). This finding was consistent with Weiser's work (2000) that reported females use internet for interpersonal communication, lesser extent, and academic assistance while men use it as entertainment and leisure.

However, very few studies on students' internet access and ISE had been conducted in Indonesia. As one of the developing countries, by 30 June 2017, Indonesia's internet penetration rate has reached $50.4 \%$ of the total population (Internet World Stats, 2010). It is slightly lower than the world's penetration level $(51.7 \%)$. Additionally, the study on students' internet access and internet perception in the specific subject matter such as physics has not been reported. With the growth in internet-supported teaching and learning in physics, for example online discussion (Bautista, 2013), e-assessment (Cohen \& Sasson, 2016), etc., it is crucial to investigate. Therefore, this study was intended to analyze the gender differences of students about internet access facilities, experience and frequency of accessing internet, purposes of using internet in general and in learning physics, barriers in accessing internet, perception of internet in learning physics, and ISE of urban students in Lampung Province, Indonesia. Moreover, students' grade differences were also explored.

\section{Method}

This research was a descriptive research conducted by survey method. Ten schools in the urban area of Lampung Province were randomly selected in which seven schools from Bandar Lampung City and three schools from Metro City. The total number of respondents involved in this study was 798 students with 56 - 100 respondents per school. Data collection was conducted from October to November 2016. From the 798 respondents, only 777 students $(97 \%)$ were taken into account in the analysis because they filled out the complete questionnaire. The participants consisted of 471 female students $(60.6 \%)$ and 306 $(39.4 \%)$ male students, and regarding the grade, $326(42.0 \%)$ of them were first grade, $271(34.9 \%)$ were second grade, and $180(23.2 \%)$ were third grade.

The instrument employed in this research consisted of a questionnaire and two scales. The questionnaire was partially adopted from Loan (2011), Gökalp (2013), and Kumar (2014). It was used to collect data of students' demographic profiles, computer and internet facilities, experience and frequency of accessing internet, purpose of using the internet in general and in physics learning, and barriers in accessing the internet. The scales were an ISE scale consisting of nine items and a perception scale about internet benefits in physics lessons consisting of six items. The ISE scale was a Likert scale adapted from former studies (i.e. Kao, Wu \& Tsai, 2011; Tsai \& Tsai, 2003; Wu \& Tsai, 2006). It has 5 levels of response, starting from 1 (very unconfident) to 5 (very confident). It measured students' confidence about their basic skills in searching and collecting information from the internet. All of its items were in the form of positive statements, such as "I am sure I can download files like .doc or .pdf from the internet". Meanwhile, two of the six items of perception scale were in negative statements, like "I want to access internet to search for physics material but I do not know where to find it". When calculating the average score of students' perception, the scores of negative items were converted firstly.

The validity and reliability of the scales was tested using Pearson correlation and Cronbach alpha, respectively. The validity test results show that all of the scales items were valid. Meanwhile, Cronbach 
alpha coefficients were obtained .836 and .629 for ISE scale and perception scale, respectively. Furthermore, to analyze gender and grade differences, Chi-square test, t-test, One Way ANOVA test, Mann-Whitney U test, and Kruskal-Wallis test were employed. The Chi-square test was used to examine the differences in computer and internet access ownership, experience and frequency of using the internet, and objectives and barriers in accessing the internet. T-test and Mann-Whitney $\mathrm{U}$ test were used to examine the gender differences on the ISE and internet perceptions whereas ANOVA and Kruskal-Wallis test were used to analyze their grade gap. All of the statistical tests used an alpha level of .05 .

\section{Result and Discussion}

\subsection{Gender and Grade Differences in the Internet Facility and Access}

The internet facility and access aspect covers the ownership of computer and internet, experience, and frequency of using the internet. The results of computer and internet access ownership at home were summarized in Table 1. The data showed that more than two third of students have computers/ laptops at home (80.6\%). However, only 53.8\% students have internet access via computers/ laptops. The availability of internet access via mobile phones, on the other hand, was very high, at $94.5 \%$. It indicated that the internet penetration rate of senior high school students' in the urban area of Lampung is much higher than the average internet penetration rate in Indonesia which is only $50.4 \%$ of the total population, by the data on June 2017 (Internet World Stats, 2010). Moreover, the author also found gender differences in the ownership of computers/ laptops and internet connection through mobile phones $(p=.012)$. Female students tend to have more computer and internet facilities than did male students. It is an interesting finding, since in Indonesia women generally are not considered at the same level as men. Related to this result, Tsai \& Tsai (2010) found that no significant difference in computer ownership between male and female students of junior high schools in Taiwan. This result indicates that the gender gap has seemed to be narrowing or even reversed. On the other hand, no significant differences were obtained between grades in the computer and internet access ownership at home $(p>.05)$.

\begin{tabular}{|c|c|c|c|c|c|c|c|c|}
\hline \multirow[b]{2}{*}{ Item } & \multirow{2}{*}{$\begin{array}{l}\text { Total } \\
n(\%)\end{array}$} & \multicolumn{2}{|c|}{ Gender } & \multirow[b]{2}{*}{$p$} & \multicolumn{3}{|c|}{ Grade } & \multirow[b]{2}{*}{$p$} \\
\hline & & Male & Female & & First & Second & Third & \\
\hline $\begin{array}{l}\text { 1. Ownership of computer/ } \\
\text { laptop }\end{array}$ & & & & $.012^{*}$ & & & & .373 \\
\hline -Yes & $\begin{array}{c}626 \\
(80.6)\end{array}$ & $\begin{array}{c}233 \\
(76.1)\end{array}$ & $\begin{array}{c}393 \\
(83.4)\end{array}$ & & $\begin{array}{c}255 \\
(78.2)\end{array}$ & $\begin{array}{c}223 \\
(82.3)\end{array}$ & $\begin{array}{c}148 \\
(82.2)\end{array}$ & \\
\hline$-\mathrm{No}$ & $\begin{array}{c}151 \\
(19.4)\end{array}$ & $\begin{array}{c}73 \\
(23.9)\end{array}$ & $\begin{array}{c}78 \\
(16.6)\end{array}$ & & $\begin{array}{c}71 \\
(21.8)\end{array}$ & $\begin{array}{c}48 \\
(17.7)\end{array}$ & $\begin{array}{c}32 \\
(17.8)\end{array}$ & \\
\hline $\begin{array}{l}\text { 2. Internet connection through } \\
\text { computer/ laptop at home }\end{array}$ & & & & .157 & & & & .631 \\
\hline -Yes & $\begin{array}{c}418 \\
(53.8)\end{array}$ & $\begin{array}{c}155 \\
(50.7)\end{array}$ & $\begin{array}{c}263 \\
(55.8)\end{array}$ & & $\begin{array}{c}181 \\
(55.5)\end{array}$ & $\begin{array}{c}145 \\
(53.5)\end{array}$ & $\begin{array}{c}92 \\
(51.1)\end{array}$ & \\
\hline$-\mathrm{No}$ & $\begin{array}{c}359 \\
(46.2)\end{array}$ & $\begin{array}{c}151 \\
(49.3)\end{array}$ & $\begin{array}{c}208 \\
(44.2)\end{array}$ & & $\begin{array}{c}145 \\
(44.5)\end{array}$ & $\begin{array}{c}126 \\
(46.5)\end{array}$ & $\begin{array}{c}88 \\
(48.9)\end{array}$ & \\
\hline $\begin{array}{l}\text { 3. Internet connection through } \\
\text { mobile phones/ tablet }\end{array}$ & & & & $.023^{*}$ & & & & .169 \\
\hline -Yes & $\begin{array}{c}734 \\
(94.5)\end{array}$ & $\begin{array}{c}282 \\
(92.2)\end{array}$ & $\begin{array}{c}452 \\
(96.0)\end{array}$ & & $\begin{array}{c}307 \\
(94.2)\end{array}$ & $\begin{array}{c}261 \\
(96.3)\end{array}$ & $\begin{array}{c}166 \\
(92.2) \\
\end{array}$ & \\
\hline -No & $43(5.5)$ & $24(7.8)$ & $19(4.0)$ & & $19(5.8)$ & $10(3.7)$ & $14(7.8)$ & \\
\hline
\end{tabular}

* Significant at $a=.05$

Table 1. Computer and internet access ownership at home 
The results on the experience and frequency of internet usage were presented in Table 2. More than a half of students $(55.0 \%)$ have experience of using the internet for more than five years. Only few students who have internet experience less than one year (3.2\%). It means that most students have accessed the internet from junior high school or even at elementary school. Gökalp (2013) found the similar results where $46.2 \%$ of the physics-related web users had access to the internet for 5-6 years. However, the participants varied from 10 years old - older. In terms of gender differences, the $p$ value was .513 which means that there were no significant differences found in the experience of accessing the internet. Boys had the same level of internet use experience with girls. This is in line with the findings of Tsai \& Tsai (2010), gender gap for internet using experience were no longer exist in junior high school students in Taiwan. On the grade differences, $p$ value reached a significant level of .000 , which means that grade difference existed in the experience of internet use. Students of third grade were the most superior. Thus, it can be assumed that the greater the students' grade, the more experience they have.

In line with the experience, the frequency of using the internet was also very high. More than two third of students confirmed that they accessed the internet daily (79.9\%) and $17 \%$ students accessed internet weekly (3-4 times and once in a week). Overall, only 3.0\% students in total accessed internet with the frequency of 2-3 times per month, once a month, and never. This result was very high as compared to previous study. Loan (2011) who conducted a comparative study of internet used by rural and urban college students in Srinagar found that only $28 \%$ of urban students who used internet daily. It might be different with recent condition since the global economic development. Furthermore, no significant gender gap was found on the frequency of internet use but grade gap differences existed. The study suggested that the higher the grade of students, the greater the number of students who access the internet every day.

\begin{tabular}{|c|c|c|c|c|c|c|c|c|}
\hline \multirow[b]{2}{*}{ Item } & \multirow{2}{*}{$\begin{array}{l}\text { Total } \\
n(\%)\end{array}$} & \multicolumn{2}{|c|}{ Gender } & \multirow[b]{2}{*}{$p$} & \multicolumn{3}{|c|}{ Grade } & \multirow[b]{2}{*}{$p$} \\
\hline & & Male & Female & & First & Second & Third & \\
\hline Experience of Internet Use & & & & .513 & & & & $.000^{*}$ \\
\hline$>5$ years & $\begin{array}{c}427 \\
(55.0)\end{array}$ & $\begin{array}{c}169 \\
(55.2)\end{array}$ & $\begin{array}{c}258 \\
(54.8)\end{array}$ & & $\begin{array}{c}139 \\
(42.6)\end{array}$ & $\begin{array}{c}163 \\
(60.1)\end{array}$ & $\begin{array}{c}125 \\
(69.4)\end{array}$ & \\
\hline $3-4$ years & $\begin{array}{c}208 \\
(26.8)\end{array}$ & $\begin{array}{c}85 \\
(27.8)\end{array}$ & $\begin{array}{c}123 \\
(26.1)\end{array}$ & & $\begin{array}{c}105 \\
32.2\end{array}$ & $\begin{array}{c}70 \\
25.8\end{array}$ & $\begin{array}{c}33 \\
18.3\end{array}$ & \\
\hline $1-3$ years & $\begin{array}{l}117 \\
15.1\end{array}$ & $\begin{array}{c}40 \\
13.1\end{array}$ & $\begin{array}{c}77 \\
16.4\end{array}$ & & $\begin{array}{c}62 \\
19.0\end{array}$ & $\begin{array}{c}33 \\
12.2\end{array}$ & $\begin{array}{c}22 \\
12.2\end{array}$ & \\
\hline$<1$ year & $\begin{array}{c}25 \\
(3.2)\end{array}$ & $\begin{array}{c}12 \\
(3.9)\end{array}$ & $\begin{array}{c}13 \\
(2.8)\end{array}$ & & $\begin{array}{c}20 \\
(6.1)\end{array}$ & $\begin{array}{c}5 \\
(1.8)\end{array}$ & $\begin{array}{c}0 \\
(.0)\end{array}$ & \\
\hline Frequency of Internet Use & & & & .224 & & & & $.005^{*}$ \\
\hline Daily & $\begin{array}{c}621 \\
(79.9)\end{array}$ & $\begin{array}{c}241 \\
(78.8)\end{array}$ & $\begin{array}{c}380 \\
(80.7)\end{array}$ & & $\begin{array}{c}241 \\
(73.9)\end{array}$ & $\begin{array}{c}223 \\
(82.3)\end{array}$ & $\begin{array}{c}157 \\
(87.2)\end{array}$ & \\
\hline 3-4 times/week & $\begin{array}{c}110 \\
(14.2)\end{array}$ & $\begin{array}{c}45 \\
(14.7)\end{array}$ & $\begin{array}{c}65 \\
(13.8)\end{array}$ & & $\begin{array}{c}58 \\
(17.8)\end{array}$ & $\begin{array}{c}34 \\
(12.5)\end{array}$ & $\begin{array}{c}18 \\
(10.0)\end{array}$ & \\
\hline Once a week & $\begin{array}{c}22 \\
(2.8)\end{array}$ & $\begin{array}{c}6 \\
(2.0)\end{array}$ & $\begin{array}{c}16 \\
(3.4)\end{array}$ & & $\begin{array}{c}11 \\
(3.4)\end{array}$ & $\begin{array}{c}7 \\
(2.6)\end{array}$ & $\begin{array}{c}4 \\
(2.2)\end{array}$ & \\
\hline 2-3 times/month & $\begin{array}{c}11 \\
(1.4)\end{array}$ & $\begin{array}{c}5 \\
(1.6)\end{array}$ & $\begin{array}{c}6 \\
(1.3)\end{array}$ & & $\begin{array}{c}9 \\
(2.8)\end{array}$ & $\begin{array}{c}1 \\
(.4)\end{array}$ & $\begin{array}{c}1 \\
(.6)\end{array}$ & \\
\hline Once a month & $\begin{array}{c}8 \\
(1.0)\end{array}$ & $\begin{array}{c}5 \\
(1.6)\end{array}$ & $\begin{array}{c}3 \\
(.6)\end{array}$ & & $\begin{array}{c}6 \\
(1.8)\end{array}$ & $\begin{array}{c}2 \\
(.7)\end{array}$ & $\begin{array}{c}0 \\
(.0)\end{array}$ & \\
\hline Never & $\begin{array}{c}5 \\
(.6)\end{array}$ & $\begin{array}{c}4 \\
(1.3)\end{array}$ & $\begin{array}{c}1 \\
(.2)\end{array}$ & & $\begin{array}{c}1 \\
(.3)\end{array}$ & $\begin{array}{c}4 \\
(1.5)\end{array}$ & $\begin{array}{c}0 \\
(.0)\end{array}$ & \\
\hline
\end{tabular}

"Significant at $a=.05$

Table 2. Experience and frequency of internet use 
The results on Purpose of internet use by students in general were presented in Table 3. From the nine options asked, social media was the highest purpose of students' internet use with nearly $92 \%$ of them, followed by academic purpose with a percentage close to $91 \%$ and then for entertainment of nearly $75 \%$ of students. Less than half of students accessed internet for e-mail, online shopping, and reading online newspaper or magazine. This finding is entirely different with previous study. As a comparison, Sam, Othman, Nordin (2005) found that most of the undergraduate students in a Malaysian university used internet for e-mail (98.6\%), research (95.9\%), downloading electronic papers (95.3\%), and entertainment (85.1\%). It showed the different needs among students at different levels. The needs of undergraduate students seemed to be closely related to research than high school students.

\subsection{Purposes and Barriers in Accessing the Internet}

The results of the study also revealed that there were significant differences between male and female students in motives of using the internet. The females tend to use internet primarily as academic tool and social media while males used internet more for entertainment. The similar finding is also reported by Tsai (2006) where boys prefer to use internet primarily as entertainment tool while girls prefer to use it as a communication tool. Moreover, Imhof et al. (2007) also described consistent situation where men tend to use internet as entertainment, non-academic activities than their females' peers. In contrast with gender differences, there is no significant difference found based on grades about the three objectives, but it precisely shown in six other purposes, namely online shopping, chatting, e-mail, reading online newspaper/ magazine, downloading software/ application, and searching general information. The grade differences reached .000 significant level which means the very grade gap existed in the motives of internet usage. The senior high school students of third grade always had the highest percentage compared to first and second grade.

\begin{tabular}{|c|c|c|c|c|c|c|c|c|}
\hline \multirow[b]{2}{*}{ Item } & \multirow{2}{*}{$\begin{array}{l}\text { Total } \\
n(\%)\end{array}$} & \multicolumn{2}{|c|}{ Gender } & \multirow[b]{2}{*}{$p$} & \multicolumn{3}{|c|}{ Grade } & \multirow[b]{2}{*}{$p$} \\
\hline & & Male & Female & & First & Second & Third & \\
\hline 1. Academic & $\begin{array}{c}706 \\
(90.9)\end{array}$ & $\begin{array}{c}259 \\
(84.6)\end{array}$ & $\begin{array}{c}447 \\
(94.9)\end{array}$ & $.000^{*}$ & $\begin{array}{c}301 \\
(92.3)\end{array}$ & $\begin{array}{c}249 \\
(91.9) \\
\end{array}$ & $\begin{array}{c}156 \\
(86.7)\end{array}$ & .082 \\
\hline 2. Social Media & $\begin{array}{c}714 \\
(91.9)\end{array}$ & $\begin{array}{c}271 \\
(88.6)\end{array}$ & $\begin{array}{c}443 \\
(94.1)\end{array}$ & $.006^{*}$ & $\begin{array}{c}292 \\
(89.6)\end{array}$ & $\begin{array}{c}252 \\
(93.0)\end{array}$ & $\begin{array}{c}170 \\
(94.4)\end{array}$ & .113 \\
\hline 3. Online Shopping & $\begin{array}{c}269 \\
(34.6)\end{array}$ & $\begin{array}{c}103 \\
(33.7)\end{array}$ & $\begin{array}{c}166 \\
(35.2)\end{array}$ & .650 & $\begin{array}{c}108 \\
(33.1)\end{array}$ & $\begin{array}{c}79 \\
(29.2)\end{array}$ & $\begin{array}{c}82 \\
(45.6)\end{array}$ & $.001^{*}$ \\
\hline 4. E-mail & $\begin{array}{c}295 \\
(38.0)\end{array}$ & $\begin{array}{c}105 \\
(34.3)\end{array}$ & $\begin{array}{c}190 \\
(40.3)\end{array}$ & .091 & $\begin{array}{c}108 \\
(33.1)\end{array}$ & $\begin{array}{c}90 \\
(33.2)\end{array}$ & $\begin{array}{c}97 \\
(53.9)\end{array}$ & $.000^{*}$ \\
\hline 5. Chatting & $\begin{array}{c}499 \\
(64.2)\end{array}$ & $\begin{array}{c}190 \\
(62.1)\end{array}$ & $\begin{array}{c}309 \\
(65.6)\end{array}$ & .318 & $\begin{array}{c}185 \\
(56.7)\end{array}$ & $\begin{array}{c}177 \\
(65.3)\end{array}$ & $\begin{array}{c}137 \\
(76.1)\end{array}$ & $.000^{*}$ \\
\hline 6. Reading online news & $\begin{array}{c}206 \\
(26.5)\end{array}$ & $\begin{array}{c}91 \\
(29.7)\end{array}$ & $\begin{array}{c}115 \\
(24.4)\end{array}$ & .101 & $\begin{array}{c}67 \\
(20.6)\end{array}$ & $\begin{array}{c}75 \\
(27.7)\end{array}$ & $\begin{array}{c}64 \\
(35.6)\end{array}$ & $.001^{*}$ \\
\hline 7. Entertainment & $\begin{array}{c}581 \\
(74.8)\end{array}$ & $\begin{array}{c}244 \\
(79.7)\end{array}$ & $\begin{array}{c}337 \\
(71.5)\end{array}$ & $.010^{*}$ & $\begin{array}{c}236 \\
(72.4)\end{array}$ & $\begin{array}{c}198 \\
(73.1)\end{array}$ & $\begin{array}{c}147 \\
(81.7)\end{array}$ & .051 \\
\hline $\begin{array}{l}\text { 8. Downloading software/ } \\
\text { application }\end{array}$ & $\begin{array}{c}395 \\
(50.8)\end{array}$ & $\begin{array}{c}149 \\
(48.7)\end{array}$ & $\begin{array}{c}246 \\
(52.2)\end{array}$ & .335 & $\begin{array}{c}138 \\
(42.3)\end{array}$ & $\begin{array}{c}140 \\
(51.7)\end{array}$ & $\begin{array}{c}117 \\
(65.0)\end{array}$ & $.000^{*}$ \\
\hline 9. General information & $\begin{array}{c}517 \\
(66.5)\end{array}$ & $\begin{array}{c}192 \\
(62.7)\end{array}$ & $\begin{array}{c}326 \\
(69.2)\end{array}$ & .071 & $\begin{array}{c}204 \\
(62.6)\end{array}$ & $\begin{array}{c}161 \\
(59.4)\end{array}$ & $\begin{array}{c}153 \\
(85.0)\end{array}$ & $.000^{*}$ \\
\hline
\end{tabular}

${ }^{*}$ Significant at $a=.05$

Table 3. General purpose of students' internet use 
In order to get further information of gender and grade gap in the purpose of internet usage as academic assistant, this study also explored the internet utilization in learning physics. It can be seen from Table 4 that most students tend to use internet for doing physics homework $(78.0 \%)$ and searching for physics material (67.7\%). Only few students (13.1\%) use internet for e-learning/ online learning. Also, the gender differences of internet utilization achieved a significant level at $\alpha=.05$ for searching of physics videos, searching of physics animations, and doing physics tasks. It reflects that a very gender gap existed in the motives of accessing the internet. Girls were reported more excellent in using internet in terms of physics tasks while men more skilful in terms of internet use to search for physics videos and animations. This suggests that females and males seemed to have different motives and interest in using internet. In contrast, there is no significant difference between students' grades.

Besides exploring the gap between gender and grade in internet utilization, this study also tried to explore the students' barriers to use the internet. The data on Table 5 showed that the poor internet connection was reported as the only most problem experienced by urban students when they had to use internet $(89.2 \%)$. Other problems were only experienced by less than a half of the students, such as difficult to find information $(35.6 \%)$, financial problem $(28.8 \%)$, too much information on the internet $(21.2 \%)$, and lack of time in accessing the internet (5.1\%). Other barriers stated by very few students were Internet data packets exhausting, internet networks disturbing, and annoying advertisements on the internet. This finding is different with Kumar (2014) who revealed that the most problem encountered by physics education students at Kurukshetra University was too much information on the internet (61.4\%). About the internet speed barrier, only $56.8 \%$ of students experienced it. Loan (2011), on the other hand, found different results where information overload was the most problem faced by urban college students, as many $44.8 \%$.

Based on the $p$ value of the slow internet connection item, it is known that there are significant differences in terms of gender and grade students. Females were reported as more percentage who experienced barriers slow internet connection than male students. For grade, the higher the grade, the more percentage number of students experience this obstacle. The differentiation of the grade aspect seems to correspond to the differences in experience and frequency of previous students' internet usage where the experience and frequency of students' internet use are higher in line with the high grade of students.

\begin{tabular}{|c|c|c|c|c|c|c|c|c|}
\hline \multirow[b]{2}{*}{ Item } & \multirow{2}{*}{$\begin{array}{l}\text { Total } \\
n(\%)\end{array}$} & \multicolumn{2}{|c|}{ Gender } & \multirow[b]{2}{*}{$p$} & \multicolumn{3}{|c|}{ Grade } & \multirow[b]{2}{*}{$p$} \\
\hline & & Male & Female & & First & Second & Third & \\
\hline 1. Browsing of physics material & $\begin{array}{c}526 \\
(67.7)\end{array}$ & $\begin{array}{c}197 \\
(64.4)\end{array}$ & $\begin{array}{c}329 \\
(69.9)\end{array}$ & .111 & $\begin{array}{c}236 \\
(72.4)\end{array}$ & $\begin{array}{c}176 \\
(64.9)\end{array}$ & $\begin{array}{c}114 \\
(63.3)\end{array}$ & .055 \\
\hline 2. Searching of physics video & $\begin{array}{c}151 \\
(19.4)\end{array}$ & $\begin{array}{c}74 \\
(24.2)\end{array}$ & $\begin{array}{c}77 \\
(16.3)\end{array}$ & $.007^{*}$ & $\begin{array}{c}56 \\
(17.2)\end{array}$ & $\begin{array}{c}53 \\
(19.6)\end{array}$ & $\begin{array}{c}42 \\
(23.3)\end{array}$ & .245 \\
\hline 3. Searching of physics animation & $\begin{array}{c}154 \\
(19.8)\end{array}$ & $\begin{array}{c}74 \\
(24.4)\end{array}$ & $\begin{array}{c}80 \\
(17.0)\end{array}$ & $.014^{*}$ & $\begin{array}{c}68 \\
(20.9)\end{array}$ & $\begin{array}{c}55 \\
(20.3)\end{array}$ & $\begin{array}{c}31 \\
(17.2)\end{array}$ & .599 \\
\hline 4. Doing physics tasks & $\begin{array}{c}606 \\
(78.0)\end{array}$ & $\begin{array}{c}218 \\
(71.2)\end{array}$ & $\begin{array}{c}388 \\
(82.4)\end{array}$ & $.000^{*}$ & $\begin{array}{c}251 \\
(77.0)\end{array}$ & $\begin{array}{c}214 \\
(79.0)\end{array}$ & $\begin{array}{c}141 \\
(78.3)\end{array}$ & .839 \\
\hline $\begin{array}{l}\text { 5. Joining e-learning/online } \\
\text { learning }\end{array}$ & $\begin{array}{c}102 \\
(13.1)\end{array}$ & $\begin{array}{c}42 \\
(13.7)\end{array}$ & $\begin{array}{c}166 \\
(35.2)\end{array}$ & .691 & $\begin{array}{c}43 \\
(13.2)\end{array}$ & $\begin{array}{c}28 \\
(10.3)\end{array}$ & $\begin{array}{c}98 \\
(54.4)\end{array}$ & .105 \\
\hline 6. Engage in discussion group & $\begin{array}{c}164 \\
(21.1)\end{array}$ & $\begin{array}{c}66 \\
(21.6)\end{array}$ & $\begin{array}{c}98 \\
(20.8)\end{array}$ & .799 & $\begin{array}{c}80 \\
(24.5)\end{array}$ & $\begin{array}{c}48 \\
(17.7)\end{array}$ & $\begin{array}{c}36 \\
(20.0)\end{array}$ & .116 \\
\hline 7. Searching of physics exercises & $\begin{array}{c}432 \\
(55.6)\end{array}$ & $\begin{array}{c}165 \\
(53.9)\end{array}$ & $\begin{array}{c}267 \\
(56.7)\end{array}$ & .448 & $\begin{array}{c}172 \\
(52.8)\end{array}$ & $\begin{array}{c}162 \\
(59.8)\end{array}$ & $\begin{array}{c}98 \\
(54.4)\end{array}$ & .215 \\
\hline 8. Doing exercises & $\begin{array}{c}217 \\
(27.9)\end{array}$ & $\begin{array}{c}88 \\
(28.8)\end{array}$ & $\begin{array}{c}129 \\
(27.4)\end{array}$ & .678 & $\begin{array}{c}98 \\
(30.1)\end{array}$ & $\begin{array}{c}74 \\
(27.3)\end{array}$ & $\begin{array}{c}45 \\
(25.0)\end{array}$ & .459 \\
\hline
\end{tabular}

"Significant at $a=.05$

Table 4. Purpose of internet use by students related to learning physics 


\begin{tabular}{|c|c|c|c|c|c|c|c|c|}
\hline \multirow{2}{*}{ Item } & \multirow{2}{*}{$\begin{array}{l}\text { Total } \\
n(\%)\end{array}$} & \multirow{2}{*}{$\begin{array}{l}\text { Male } \\
n(\%)\end{array}$} & \multirow{2}{*}{$\begin{array}{c}\text { Female } \\
n(\%)\end{array}$} & \multirow{2}{*}{$p$} & \multicolumn{3}{|c|}{ Grade } & \multirow{2}{*}{$p$} \\
\hline & & & & & First & Second & Third & \\
\hline 1. Bad internet connection & $\begin{array}{c}693 \\
(89.2)\end{array}$ & $\begin{array}{c}263 \\
(85.9)\end{array}$ & $\begin{array}{c}430 \\
(91.3)\end{array}$ & $.019^{*}$ & $\begin{array}{c}279 \\
(85.6)\end{array}$ & $\begin{array}{c}246 \\
(90.8)\end{array}$ & $\begin{array}{c}168 \\
(93.3)\end{array}$ & $.016^{*}$ \\
\hline 2. difficult to find information & $\begin{array}{c}277 \\
(35.6)\end{array}$ & $\begin{array}{c}100 \\
(32.7)\end{array}$ & $\begin{array}{c}177 \\
(37.6)\end{array}$ & .164 & $\begin{array}{c}111 \\
(34.0)\end{array}$ & $\begin{array}{c}93 \\
(34.3)\end{array}$ & $\begin{array}{c}73 \\
(40.6)\end{array}$ & .292 \\
\hline 3. Too much information & $\begin{array}{c}165 \\
(21.2) \\
\end{array}$ & $\begin{array}{c}64 \\
(20.9) \\
\end{array}$ & $\begin{array}{c}101 \\
(21.4) \\
\end{array}$ & .860 & $\begin{array}{c}61 \\
(18.7) \\
\end{array}$ & $\begin{array}{c}58 \\
(21.4) \\
\end{array}$ & $\begin{array}{c}46 \\
(25.6) \\
\end{array}$ & .196 \\
\hline 4. Lack of time & $\begin{array}{c}40 \\
(5.1) \\
\end{array}$ & $\begin{array}{c}17 \\
(5.6) \\
\end{array}$ & $\begin{array}{c}23 \\
(4.9) \\
\end{array}$ & .056 & $\begin{array}{c}15 \\
(4.6) \\
\end{array}$ & $\begin{array}{c}10 \\
(3.7) \\
\end{array}$ & $\begin{array}{c}15 \\
(8.3) \\
\end{array}$ & .425 \\
\hline 5. High cost & $\begin{array}{c}224 \\
(28.8) \\
\end{array}$ & $\begin{array}{c}100 \\
(32.7) \\
\end{array}$ & $\begin{array}{c}124 \\
(26.3)\end{array}$ & .679 & $\begin{array}{c}89 \\
(27.3) \\
\end{array}$ & $\begin{array}{c}86 \\
(31.7) \\
\end{array}$ & $\begin{array}{c}49 \\
(27.2) \\
\end{array}$ & .077 \\
\hline 6. Other & $\begin{array}{c}18 \\
(2.3)\end{array}$ & $\begin{array}{c}7 \\
(2.3)\end{array}$ & $\begin{array}{c}11 \\
(2.3)\end{array}$ & - & $\begin{array}{c}6 \\
(1.8)\end{array}$ & $\begin{array}{c}3 \\
(1.1)\end{array}$ & $\begin{array}{c}5 \\
(2.8) \\
\end{array}$ & - \\
\hline
\end{tabular}

Significant at $a=.05$

Table 5. Barriers faced by Students

\subsection{Internet Self-Efficacy (ISE) and Perception toward the Benefit of Internet in Learning Physics}

Furthermore, Table 6 shows that students' ISE, in average, is categorized as high, 4.09 out of 5. Based on gender difference, there are two significantly different ISE scores between male and female students, i.e., "I believe I can enter the URL of the site directly to open a web" and "I believe I can make bookmarks for an important web". Males are higher than females in both items. In total, males' ISE was slightly higher than females' yet there was no statistically significant difference at $\alpha=.05(p=.051)$. This finding confirms previous trend of research results that gender gap on basic ISE has been disappeared. In the basics skill, women tend to have the same level of self-reported internet skills as men.

From students' grade point of view, overall, significant differences of ISE found between students' grade. Students' ISE tends to be higher for higher grades. When viewed per item, significant differences are found in three items from nine. It seems to be corresponding with the grade differences in experience and frequency of using internet in Table 2.

Unlike the ISE, as it can be seen in Table 7, students' perception about the benefits of internet in physics learning was found significantly different based on gender of students. By gender, female students have significantly higher perceptions $(p<.05)$ than their male counterparts. In detail, women's score of negative statement items were better than men's. It might positively correlate with the high frequency of women in using the internet for academic purposes presented in Table 3 and for solving physics problems/ homework in Table 4. Meanwhile, based on grade, there was no significant difference at $a=.05$. However, the significance on grade existed at $a=.10$. First grade students have slightly higher average score of perception. This seems in contrast to the experience and frequency of students' internet use and students' ISE. Students with higher internet experience, frequency, and ISE tend to have lower perceptions about the benefits of the internet in learning physics. 


\begin{tabular}{|c|c|c|c|c|c|c|c|c|c|}
\hline \multirow[b]{2}{*}{ No } & \multirow[b]{2}{*}{ Item } & \multirow{2}{*}{$\begin{array}{l}\text { Total } \\
(\bar{x}, \sigma)\end{array}$} & \multicolumn{2}{|c|}{ Gender } & \multirow{2}{*}{$\begin{array}{c}t(z) \\
p\end{array}$} & \multicolumn{3}{|c|}{ Grade } & \multirow{2}{*}{$\begin{array}{c}F\left(\chi^{2}\right) \\
p\end{array}$} \\
\hline & & & Male & Female & & First & Second & Third & \\
\hline \multirow{2}{*}{1} & I know how to use web & 4.35 & 4.41 & 4.32 & 1.63 & 4.25 & 4.43 & 4.43 & 5.24 \\
\hline & browser & (.75) & (.81) & $(.70)$ & .103 & (.69) & (.78) & (.77) & $.006^{*}$ \\
\hline \multirow{2}{*}{2} & I am able to look for & 4.06 & 4.10 & 4.03 & $-1.86^{a}$ & 3.96 & 4.14 & 4.11 & $10.88^{\mathrm{b}}$ \\
\hline & information on website & (.83) & $(.89)$ & $(.80)$ & .064 & $(.84)$ & (.88) & $(.74)$ & $.004^{*}$ \\
\hline \multirow{2}{*}{3} & I can use web browser like & 4.18 & 4.22 & 4.15 & 1.12 & 4.05 & 4.30 & 4.25 & 7.61 \\
\hline & $\begin{array}{l}\text { Mozilla Firefox to search } \\
\text { information }\end{array}$ & $(.84)$ & $(.85)$ & (.83) & .263 & $(.90)$ & $(.74)$ & $(.82)$ & $.001^{*}$ \\
\hline \multirow{2}{*}{4} & I believe I can open & 4.19 & 4.24 & 4.16 & 1.22 & 4.14 & 4.16 & 4.32 & 2.84 \\
\hline & hyperlinks on a website & $(.86)$ & (.84) & $(.86)$ & .222 & (.86) & $(.91)$ & (.75) & .059 \\
\hline \multirow{2}{*}{5} & I believe I can enter URL & 3.98 & 4.07 & 3.91 & 2.25 & 3.89 & 4.03 & 4.06 & 2.47 \\
\hline & site directly to open web & (.93) & $(.91)$ & $(.94)$ & $.025^{*}$ & $(.92)$ & $(.93)$ & (.95) & .085 \\
\hline \multirow{2}{*}{6} & I believe I can make & 3.33 & 3.51 & 3.22 & $-3,86^{a}$ & 3.25 & 3.39 & 3.40 & 1.87 \\
\hline & bookmark for important web & $(1.05)$ & $(1.09)$ & $(1.01)$ & $.000^{*}$ & $(1.02)$ & $(1.04)$ & $(1.11)$ & .154 \\
\hline \multirow{2}{*}{7} & I believe I can print out & 4.06 & 4.04 & 4.07 & -.39 & 4.01 & 4.10 & 4.07 & .66 \\
\hline & important info. from web & $(.94)$ & $(.96)$ & (.93) & 699 & $(.91)$ & $(.95)$ & $(.97)$ & .518 \\
\hline \multirow{2}{*}{8} & I believe I can download file & 4.13 & 4.12 & 4.13 & -.09 & 4.06 & 4.20 & 4.13 & 1.68 \\
\hline & from internet & $(.90)$ & $(.96)$ & (.85) & .930 & $(.89)$ & $(.85)$ & $(.97)$ & .186 \\
\hline \multirow{2}{*}{9} & I believe I can copy texts & 4.52 & 4.54 & 4.51 & .48 & 4.45 & 4.58 & 4.56 & $3.94^{\mathrm{b}}$ \\
\hline & from web to Microsoft Word & $(.75)$ & $(.77)$ & $(.73)$ & .628 & $(.83)$ & $(.69)$ & $(.65)$ & .139 \\
\hline \multirow{2}{*}{\multicolumn{2}{|c|}{ Overall }} & 4.09 & 4.14 & 4.06 & 1.95 & 4.01 & 4.15 & 4.15 & 5.78 \\
\hline & & $(.57)$ & (.58) & $(.57)$ & .051 & (.58) & $(.57)$ & (.55) & $.003^{*}$ \\
\hline
\end{tabular}

"Significant at $a=.05{ }^{\mathrm{a}}{ }^{\mathrm{z}} \mathrm{\text {of }}$ Mann-Whitney test; ${ }^{\mathrm{b}} \chi^{2}$ of Kruskal-Wallis test

Table 6. Students' internet self-efficacy

\begin{tabular}{|c|c|c|c|c|c|c|c|c|c|}
\hline \multirow[b]{2}{*}{ No } & \multirow[b]{2}{*}{ Item } & \multirow{2}{*}{$\begin{array}{l}\text { Total } \\
(\bar{x}, \sigma)\end{array}$} & \multicolumn{2}{|c|}{ Gender } & \multirow{2}{*}{$\begin{array}{c}t(z) \\
p\end{array}$} & \multicolumn{3}{|c|}{ Grade } & \multirow{2}{*}{$\begin{array}{c}F\left(\chi^{2}\right), \\
p\end{array}$} \\
\hline & & & Male & Female & & First & Second & Third & \\
\hline \multirow{2}{*}{1} & \multirow{2}{*}{$\begin{array}{l}\text { Internet helps me to find } \\
\text { physics materials }\end{array}$} & 4.30 & 4.25 & 4.33 & -1.71 & 4.31 & 4.25 & 4.35 & 1.32 \\
\hline & & $(.70)$ & $(.76)$ & (.66) & .088 & (.62) & (.82) & (.65) & .269 \\
\hline \multirow{2}{*}{2} & \multirow{2}{*}{$\begin{array}{l}\text { Internet helps me to solve } \\
\text { my physics tasks }\end{array}$} & 3.98 & 3.96 & 4.00 & $-.48^{a}$ & 4.03 & 3.93 & 3.99 & 1.35 \\
\hline & & (.75) & (.81) & (.71) & .635 & $(.72)$ & (.75) & (.82) & .259 \\
\hline \multirow{2}{*}{3} & \multirow{2}{*}{$\begin{array}{l}\text { Internet helps me to prepare } \\
\text { my examination }\end{array}$} & 3.65 & 3.66 & 3.64 & $-.34^{a}$ & 3.74 & 3.64 & 3.50 & $7.52^{\mathrm{b}}$ \\
\hline & & (.93) & $(.98)$ & $(.90)$ & .734 & (.89) & $(.95)$ & $(.97)$ & $.023^{*}$ \\
\hline \multirow{2}{*}{4} & \multirow{2}{*}{$\begin{array}{l}\text { I want to access internet to } \\
\text { find Physics materials but I } \\
\text { do not know where to find it }\end{array}$} & 3.49 & 3.26 & 3.64 & $-4.55^{\mathrm{a}}$ & 3.53 & 3.38 & 3.60 & 2.56 \\
\hline & & $(1.09)$ & (1.16) & (1.01) & $.000^{*}$ & (1.09) & (1.04) & (1.14) & .078 \\
\hline \multirow{2}{*}{5} & \multirow{2}{*}{$\begin{array}{l}\text { Internet makes me easier to } \\
\text { learn physics }\end{array}$} & 3.70 & 3.72 & 3.69 & .50 & 3.83 & 3.62 & 3.58 & $13.6^{\mathrm{b}}$ \\
\hline & & $(.90)$ & $(.91)$ & $(.89)$ & .619 & (.84) & $(.90)$ & $(.97)$ & $.001^{*}$ \\
\hline \multirow[b]{2}{*}{6} & \multirow{2}{*}{$\begin{array}{l}\text { Using internet is confusing } \\
\text { rather than helping me in } \\
\text { understanding Physics }\end{array}$} & 3.48 & 3.39 & 3.54 & $-2.01^{a}$ & 3.50 & 3.56 & 3.34 & 2.50 \\
\hline & & (1.04) & (1.11) & $(.98)$ & $.045^{*}$ & (1.01) & (1.06) & (1.05) & .083 \\
\hline \multirow{2}{*}{\multicolumn{2}{|c|}{ Average }} & 3.77 & 3.71 & 3.81 & $-2,58$ & 3.82 & 3.73 & 3.73 & $5.52^{\mathrm{b}}$ \\
\hline & & $(.90)$ & $(.96)$ & & $.010^{*}$ & (.86) & & (.93) & .063 \\
\hline
\end{tabular}

*Significant at $a=.05$; ${ }^{\mathrm{a}}$ z of Mann-Whitney test; ${ }^{\mathrm{b}} \chi^{2}$ of Kruskal-Wallis test

Table 7. Students' perceptions about the benefit of internet in learning physics

\section{Conclusions}

Based on the results and discussion, this study highlighted some important change in many areas/ aspects of the gender gap. The shifted was found in the ownership of internet access in urban students in Lampung. Females are reported having better internet facilities, and more positive perceptions toward the benefit of internet in learning physics than their males' peers. This might suggest that the gap in gender 
seems to be narrowing or even reversed as well as found by previous authors (Imhof et al., 2007; Popovic et al., 2008). Moreover, there were no gender differences among students on the experience and frequency of accessing the internet. In contrast, a significant gender gap was found in motives of internet usage. Female students tend to use internet more for academic tools while male students use it more for entertainment. In physics, more females use internet as academic assistant to help them solving physics tasks meanwhile more males use it for accessing physics videos and animations. This may imply that gender gap still existed in the purpose of using the internet. Regarding the grade, there was no gap on computers and internet access ownership, internet usage in physics lessons, and perceptions of internet benefits in learning physics. Significant differences between grades were found in the experience and frequency of using internet, internet use for general purposes, and ISE. It indicated that higher grades have greater percentage the students of them.

Finally, this study suggests that physics teacher at senior high schools should take into account the differences of students' internet facilities, online motives, and learning preferences before implementing internet-supported learning, such as e-learning and blended learning. The results of this study are limited by the number of participants and area covered. Thus, future studies may explore the use of internet in other subject matters. Further investigations about the use of social media in academic field, including in teaching and learning physics may also be examined since it attracts the greatest number of students nowadays.

\section{Declaration of Conflicting Interests}

The author declared no potential conflicts of interest with respect to the research, authorship, and/or publication of this article.

\section{Funding}

This research was funded by the Institute of Research and Community Service, University of Lampung with Contract No. 808/UN26.21/PP/2017.

\section{References}

Bautista, R.G. (2013). The reciprocal determinism of online scaffolding in sustaining a community of inquiry n physics. Journal of Technology and Science Education, 3(2), 89-97. https://doi.org/10.3926/jotse.75

Cohen, D., \& Sasson, I. (2016). Online quizzes in a virtual learning environment as a tool for formative assessment. Journal of Technology and Science Education, 6(3), 188-208. https://doi.org/10.3926/jotse.217

Gökalp, M.S. (2013). Perceptions of the internet and education: A study with physics education website users. International Journal of Environmental and Science Education, 8(2), 289-302. https://doi.org/10.12973/ijese.2013.210a

Goktas, Y., Gedik, N., \& Baydas, O. (2013). Enablers and barriers to the use of ICT in primary schools in Turkey: A comparative study of 2005-2011. Computers and Education, 68, 211-222. https://doi.org/10.1016/j.compedu.2013.05.002

Imhof, M., Vollmeyer, R., \& Beierlein, C. (2007). Computer use and the gender gap: the issue of access, use, motivation, and performance. Computers in Human Behavior, 23(6), 2823-2837. https://doi.org/10.1016/j.chb.2006.05.007

Internet World Stats. (2010). https://www.internetworldstats.com/stats.htm (Accessed: December 2017).

Kao, C., Wu, Y., \& Tsai, C. (2011). Elementary school teachers' motivation toward web-based professional development, and the relationship with Internet self-efficacy and belief about web-based learning. Teacbing and Teacher Education, 27(2), 406-415. https://doi.org/10.1016/j.tate.2010.09.010 
Kumar, R. (2014). Internet Access and Use among Students of Physical Education: A Study of Kurukshetra University, Kurukshetra. Journal of Information Science Theory and Practice, 2(2), 59-68. https://doi.org/10.1633/JISTaP.2014.2.2.5

Loan, F.A. (2011). Internet Use by Rural and Urban College Students: A Comparative Study. DESIDOC Journal of Library \& Information Technology, 31(6), 431-436. https://doi.org/10.14429/djlit.31.6.1317

Nelson, L.J., \& Cooper, J. (1997). Gender differences in children's reactions to success and failure with computers. Computers in Human Behavior, 13(2), 247-267. https://doi.org/10.1016/S0747-5632(97)00008-3

Popovic, P.M., Gullekson, N., Morris, S., \& Morse, B. (2008). Comparing attitudes towards computer usage by undergraduates from 1986 to 2005. Computers in Human Behavior, 24(3), 986-992. https://doi.org/10.1016/j.chb.2007.03.002

Sam, H.K., Othman, A.E.A., \& Nordin, Z.S. (2005). Computer self-efficacy, computer anxiety, and attitudes toward the Internet: A study among undergraduates in Unimas. Educational Technology \& Society, 8(4), 205-219.

Schumacher, P., \& Morahan-Martin, J. (2001). Gender, internet and computer attitudes and experiences. Computers in Human Behavior, 17(1), 95-110. https:// doi.org/10.1016/S0747-5632(00)00032-7

Thanuskodi, S. (2013). Gender Differences in Internet Usage among College Students: A Comparative Study, Library Philosophy and Practice (e-journal), 1052.

Tsai, C.-C. (2006). What is the Internet? Taiwanese high school students' perceptions. Cyberpsychology \& Behavior, 9(6), 767-771. https://doi.org/10.1089/cpb.2006.9.767

Tsai, M.J., \& Tsai, C.C. (2003). Information Searching Strategies in Web-based Science Learning: The Role of Internet Self-efficacy. Innovations in Education and Teaching International, 40(1), 43-50.

https://doi.org/10.1080/1355800032000038822

Tsai, M.J., \& Tsai, C.C. (2010). Junior high school students' Internet usage and self-efficacy: A re-examination of the gender gap. Computers and Education, 54(4), 1182-1192.

https://doi.org/10.1016/j.compedu.2009.11.004

Vekiri, I., \& Chronaki, A. (2008). Gender issues in technology use: Perceived social support, computer self-efficacy and value beliefs, and computer use beyond school. Computers and Education, 51(3), 1392-1404. https://doi.org/10.1016/j.compedu.2008.01.003

Weiser, E.B. (2000). Gender Differences in Internet Use Patterns and Internet Application Preferences: A Two-Sample Comparison. Cyberpsychology \& Behavior, 3(2), 167-178.

https://doi.org/10.1089/109493100316012

Wu, Y.T., \& Tsai, C.C. (2006). University Students' Internet Attitudes and Internet Self-Efficacy: AStudy at Three Universities in Taiwan. Cyberpsychology \& behavior, 9(4), 441-450.

https://doi.org/10.1089/cpb.2006.9.441

Zhou, G., \& Xu, J. (2007). Adoption of Educational Technology: How Does Gender Matter? International Journal of Teaching and Learning in Higher Education, 19(2), 140-153.

Published by OmniaScience (www.omniascience.com)

Journal of Technology and Science Education, 2018 (www.jotse.org)

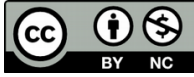

Article's contents are provided on an Attribution-Non Commercial 4.0 Creative commons International License. Readers are allowed to copy, distribute and communicate article's contents, provided the author's and JOTSE journal's names are included. It must not be used for commercial purposes. To see the complete licence contents, please visit https://creativecommons.org/licenses/by-nc/4.0/. 